\title{
Role of Endoglin Expression in Acute Myeloblastic Leukemia
}

\author{
SARAH S. ABD EL-GHANY, M.Sc.*; AMIRA Y. AHMED, M.D.*; AMR M. GAWALY, M.D.** and \\ SAHAR M. HAZZAA, M.D.* \\ The Departments of Clinical Pathology* and Internal Medicine**, Faculty of Medicine, Tanta University
}

\begin{abstract}
Background: Endoglin (CD105), a cell membrane glycoprotein of approximately $180 \mathrm{kDa}$, has been described as a proliferation-associated antigen of leukemia and endothelial cells, and it represents a powerful marker to quantify tumor angiogenesis. CD105 expression is higher on leukemic cells with immature morphological and phenotypic characteristics compared to normal hematopoietic progenitors. Higher amounts of sCD105 were measured in AML and Chronic Myeloproliferative Disorders (CMD) patients than in healthy subjects. CD105 is involved in the control of vascular endothelial cell proliferation, adhesion and migration. CD105 might have a direct involvement in cancer by increase of tumor mass. CD105 levels may be useful as an indicator for disease progression and to identify patients at risk of recurrence and metastasis.
\end{abstract}

Aim of Study: Our aim is to evaluate the role of endoglin (CD 105) expression in patients with AML to clarify its role as a prognostic marker.

Material and Methods: This study was carried out on 50 patients with newly diagnosed acute myeloid leukemia who attended the Hematology/Oncology Unit of Tanta University Hospitals. The patients were selected for the study on the basis of standard clinical, hematological and immune phenotypic criteria for diagnosis of AML. CD105 expression was measured in bone marrow aspirate of AML patients using RD SYSTEMS kits and BD FACS calibur.

Subjects included in this study were divided into two groups according to CD 105 exppression; positive and negative groups and classified according to FAB subtypes and immunophenotypic features.

Results: There was a significant difference in distribution of CD105 expression in different FAB subtypes. There was a significant positive correlation between CD 105 expression and $\mathrm{Hb}$ concentration, WBCs count and blast count in peripheral blood and BM. There was no significant correlation between CD105 expression and platelets count and serum LDH level. Kaplan-Meier survival curve show significant higher overall survival and disease free survival in negative

Correspondence to: Dr. Sarah Samy Abd El-Ghany, The Department of Clinical Pathology, Faculty of Medicine, Tanta University
CD105 expression group than in positive CD105 expression group.

Conclusions: Positive CD105 expression levels are associated with a bad outcome in AML patients and its expression can be easy determined in routine flow cytometric analysis. Therefore, it should be regularly investigated as a bad prognostic factor for assessment of AML patients.

Key Words: Acute myeloid leukemia (AML) - Flow cytometry - Endoglin (CD105).

\section{Introduction}

ACUTE Myeloid Leukemia (AML) is a heterogeneous clonal disorder of haemopoietic progenitor cells. The myeloid blasts expand in the peripheral blood, bone marrow, and/or other tissues, with lose the ability to differentiate normally and to respond to normal regulators of proliferation [1]. It is the most common form of acute leukemia among adults which increase due to ageing [2].

The outcome for adults with AML depends on a variety of factors, including age, intensity of post remission therapy, and biologic characteristics of the disease, intratumoral microvessel density and the cytogenetics at presentation [3] .

Angiogenesis is a physiologic process of new blood vessels formation which essential for the development and progression of malignancies [4] Acute leukemia and myelodysplastic syndromes are associated with a substantial increase in bone marrow vascularity, with an increase in the levels of various angiogenic factors [5]

CD 105 is a cell membrane glycoprotein mainly expressed on endothelial cells and overexpressed on tumor-associated vascular endothelium, which functions as an accessory component of the transforming growth factor- $P$ receptor complex and is 
involved in vascular development and remodeling, so have a prognostic significance in neoplasias [6]

Myeloid hematopoietic malignancies show elevated level of soluble CD105 in both acute myeloid leukemia and chronic disorders [6]. It is of interest that endothelial cells in bone marrow involved by AML did not express CD105, even when CD105 was strongly expressed by AML blasts. This might be related to the presence of AML in the BM with easy access to blood in contrast with solid tumors so, no need to increase their own vascularity [7]

Endoglin (CD105) could aid in tumor imaging, therapeutic targeting by antiangiogenetic medications and usage of anti-CD 105 antibody conjugated with immunotoxins and immunoradioisotopes to efficiently suppress tumor growth without any significant systemic side effects [8].

\section{Aim and objectives:}

The aim of this study is to evaluate the role of endoglin (CD105) expression in patients with AML to clarify its role as a prognostic marker.

\section{Material and Methods}

After research ethical committee approval and informed written consent from all participants in this research, this study was carried out on 50 patients with newly diagnosed AML patients who attended the Hematology/Oncology Unit, Internal Medicine Department, Tanta University Hospitals from Oct. 2016-April 2018. They were 27 males and 23 females and their ages ranged from 8 to 75 years.

\section{Inclusion criteria:}

Newly diagnosed AML patients.

\section{Exclusion criteria:}

- Any patients with malignancy other than AML.

- Any patient with chronic diseases for example COPD, chronic renal failure, coronary heart diseases and diabetes mellitus.

- Treated AML patients were also excluded.

Detailed history, clinical examination, abdominal ultrasonography, routine laboratories investigations: Complete Blood Count (CBC), Erythrocyte Sedimentation Rate (ESR), serum Lactate Dehydrogenase (LDH), BM aspiration, cytochemical study, immunophenotyping of blast cells in BM aspirate samples using the acute panel used for acute leukemia:

* Non lineage specific markers as (HLA-DR, CD34).

* Myeloid cell markers (CD 13, CD33, CD 117, cyt Anti MPO).

* Lymphoid cell markers: T-cell markers (CD2, CD7, cyt CD3), B-cell markers (CD10, CD19, Anti TDT, cyt CD 79a).

* Monocytic markers (CD64, CD14).

* Erythroid marker (glycophorin A, CD71).

* Megakaryocytic marker (CD61).

Specific laboratory investigation: Detection of CD105 expression in bone marrow samples using RD SYSTEMS kits and BD FACS calibur.

- Sampling:

- Two ml of PB were delivered into an K3 EDTA vacutainer tube for complete blood count and Giemsa stained smears.

- One ml of BM aspirate was delivered into EDTA vacutainer tube and used for immunophenotypic determination and B.M smears for morphological and cytochemical diagnosis.

- $1.6 \mathrm{ml}$ of PB on $0.4 \mathrm{ml}$ of trisodium citrate was used for ESR determination.

- One ml blood was collected into an empty tube for measurement of serum LDH.

\section{Sample preparation:}

- For each sample, set of tubes were labeled for all monoclonal antibodies used, including one tube for negative isotopic control.

- One hundred (100) gl of samples were delivered in each tube.

- Five (5) gl of negative isotopic control was added to the respective tube.

- Ten (10) gl of CD 105 was added to the respective tube.

- The tubes were vortexed and incubated in the dark at $4^{\circ} \mathrm{C}$ for 25 minutes.

- One ml of lysing solution was added to each tube.

- The tubes were vortexed and incubated for 20 minutes in the dark at $4^{\circ} \mathrm{C}$.

- The tubes were centrifuged at 2500rpm for 5 minutes and supernatant was discarded. 
- Half (0.5) $\mathrm{ml}$ of PBS as washing solution was added to each tube and mixed thoroughly.

- The tubes were centrifuged at 2500rpm for 5 minutes and the supernatant was discarded, this step was repeated.

- Cells were suspended in 300 LPAS to be ready for acquiring data by the flow cytometer.

Flow cytometric analysis:

- FACS calibur flow cytometry from Becton Dickinson was used for analysis.

- Automated cell quest software was used for data acquisition and analysis.

- The instrument setting was set by using calibrated beads provided by the manufacture.

- Isotopic quality control was used to exclude non specific binding and autoflourescence.

- 10.000 events (cells) were acquired to pass in front of laser beam.

- Light scatter histogram, forward light scatter versus log side scatter, was used to delineate cell populations of interest (blasts) by bitmap drawing (gating, surrounded by a line to separate them from other cells in the basic histogram).

- Gated fluorescence dot plot are evaluated for positive cells by using cursor position from dot plot for isotopic controls, so that $98 \%$ of positives are defined.

- The sample tubes were then introduced and processed in the same way as the control, where the monoclonal cells tagged with FITC were analyzed. The fraction of cells coated by monoclonal antibodies were determined inside the gated population of myeloblasts and assessed in a single histogram.

\section{- Data interpretation:}

In routine diagnostic work, the universal accepted cut off for positivity is $20 \%$ in AML except for MBO and CD34. As regarded CD105, a case with positive expression was defined if $20 \%$ of the gated cells or more expressed the marker.

\section{- Follow-up of the patients:}

Patients received induction therapy for AML according to $(7+3)$ regimen which includes cytarabine for 7 days through an intravenous line (IV) and anthracycline in a single IV dose for the first 3 days of treatment. Follow-up was done by frequent examination of peripheral blood and BM smears after induction therapy. If the BM did not show Complete Remission (CR) by day 28 , reinduction by anther cycle was done.

A patient had CR when the BM blast $\leq 5 \%$ with normalization of neutrophils and platelets count (neutrophils $\geq 1000 / \mathrm{cmm}$ and platelets $\geq 100000 /$ $\mathrm{cmm}$ ). Blastin $\mathrm{BM} \leq 5 \%$, recovery of neutrophils and platelets and absence of extramedullary disease considered as the cornerstone of haematological CR in patient with AML [9]

A patient was relapsed when the BM blast $\geq 5 \%$, reappearance of blast cells in peripheral blood or development of extramedullary disease [10]

The patients were followed-up for one year then the time at which the patient achieved remission, relapsed, died or last seen alive was detected for calculation of Overall Survival (OS) and the Disease Free Survival (DFS).

OS is measured from the date of diagnosis to the date of death from any cause; patients not known to have died at the last follow-up are censored on the date they were last known to be alive [10]. DFS is measured from the date of end of induction until the date of relapse or death from any cause; patients not known to have relapsed or died at the last follow-up are censored on the date they were last examined [10].

\section{- Measurements:}

Statistical presentation and analysis of the present study was conducted, using the mean, standard deviation, student $t$-test Chi-square, Kaplan-Meier curves and Linear Correlation Coefficient by SPSS V17.

Demographic data of studied AML patients: This study was conducted on 50 newly diagnosed AML patients. The studied patients were 27 males $(54 \%)$ and 23 females (46\%) with a male to female ratio of 1.17:1 figure. Their ages ranged from 8 to 75 years with a mean value of $41.54 \pm 18.46$ years.

\section{Results}

Out of the studied patients 31 patients $(62 \%)$ showed Hepatosplenomegaly (HSM) and 13 (26\%) showed lymphadenopathy.

According to FAB subtypes and immunophenotypic features, the studied cases were classified as following: 8 patients $(16 \%)$ were M1, 16 patients (32\%) were M2, 7 patients (14\%) were M3, 13 
patients $(26 \%)$ were M4, 6 patients (12\%) were M5.

According to CD105 expression patients were divided into two groups CD105 positive group and CD105 negative group (Table 1). There was a significant difference between both groups regarding CD105 expression $(p<0.001)$.

There was a significant increase in the percentage of CD105 was noted in M2, M5 and M4 subtypes and least percentage was noted in M3 ( $p=$ 0.018) (Table 3).

There was a significant positive correlation between CD105 expression and $\mathrm{Hb}$ concentration $(p<0.001)$, non significant correlation between CD105 expression and platelets count ( $p=0.584)$, a significant positive correlation between CD105 expression and WBCs count ( $p=0.030$ ), a significant positive correlation between CD105 expression and blast count in peripheral blood and $\mathrm{BM}(p$ $<0.001)$ and non significant correlation between CD105 expression and serum LDH level $(p=0.465)$ (Table 4).

Kaplan-Meier survival curve show significant higher overall survival and higher disease free survival in negative CD105 expression group than in positive CD105 expression group $(p=0.003)$ and $(p<0.001)$ respectively Figs. $(1,2)$

Table (1): CD105 expression in studied AML cases.

\begin{tabular}{lcccc}
\hline $\begin{array}{l}\text { CD105 } \\
\text { expression }(\%)\end{array}$ & $\begin{array}{c}\text { Negative } \\
(\mathrm{n}=26)\end{array}$ & $\begin{array}{c}\text { Positive } \\
(\mathrm{n}=24)\end{array}$ & $t$ & $p$ \\
\hline Min.-Max. & $4.50-19.0$ & $47.60-99.50$ & $22.785^{*}$ & $<0.001$ \\
Mean \pm SD. & $11.82 \pm 4.61$ & $84.35 \pm 15.52$ & & \\
\hline
\end{tabular}

$t, p$ : $t$ and $p$-values for student $t$-test for comparing between the two groups.

Table (2): Distribution of studied AML cases according to CD105 expression and FAB classification.

\begin{tabular}{|c|c|c|c|c|c|c|c|c|}
\hline \multirow{3}{*}{ FAB } & \multicolumn{6}{|c|}{ CD105 expression $(\%)$} & \multirow{3}{*}{$\chi^{2}$} & \multirow{3}{*}{$\begin{array}{l}{ }^{\mathrm{MC}_{p}}- \\
\text { value }\end{array}$} \\
\hline & \multicolumn{2}{|c|}{$\begin{array}{l}\text { Total } \\
(\mathrm{n}=50)\end{array}$} & \multicolumn{2}{|c|}{$\begin{array}{c}\text { Negative } \\
(n=26)\end{array}$} & \multicolumn{2}{|c|}{$\begin{array}{c}\text { Positive } \\
(n=24)\end{array}$} & & \\
\hline & No. & $\%$ & No. & $\%$ & No. & $\%$ & & \\
\hline M1 & 8 & 16.0 & 6 & 23.1 & 2 & 8.3 & $9.846^{*}$ & 0.041 \\
\hline M2 & 16 & 32.0 & 7 & 26.9 & 9 & 37.5 & & \\
\hline M3 & 7 & 14.0 & 6 & 23.1 & 1 & 4.2 & & \\
\hline M4 & 13 & 26.0 & 3 & 11.5 & 10 & 41.7 & & \\
\hline M5 & 6 & 12.0 & 4 & 15.4 & 2 & 8.3 & & \\
\hline
\end{tabular}

Table (3): Comparison of percentage of CD105 positive cells between different FAB subtypes $(n=24)$.

\begin{tabular}{|c|c|c|c|c|c|}
\hline \multirow{2}{*}{ FAB } & \multirow{2}{*}{$\mathrm{N}$} & \multicolumn{2}{|c|}{ CD105 expression (\%) } & \multirow{2}{*}{$\begin{array}{l}\text { F- } \\
\text { test }\end{array}$} & \multirow{2}{*}{$\begin{array}{c}p- \\
\text { value }\end{array}$} \\
\hline & & Min.-Max. & Mean \pm SD. & & \\
\hline M1 & 2 & $62.0-72.0$ & $67.0 \pm 7.07$ & $3.902 *$ & 0.018 \\
\hline M2 & 9 & $82.0-96.0$ & $91.73 \pm 4.59$ & & \\
\hline M3 & 1 & 47.60 & 47.60 & & \\
\hline M4 & 10 & $55.60-99.50$ & $83.83 \pm 17.52$ & & \\
\hline M5 & 2 & 84.0-95.0 & $89.50 \pm 7.78$ & & \\
\hline
\end{tabular}

$\mathrm{F}$ and $p$-values for ANOVA test.

Table (4): Correlation between CD105 expression (\%) and laboratory data in studied AML cases.

\begin{tabular}{lll}
\hline & \multicolumn{2}{c}{ CD105 expression (\%) } \\
\cline { 2 - 3 } & \multicolumn{1}{c}{$r_{\mathrm{s}}$} & \multicolumn{1}{c}{$p$} \\
\hline $\mathrm{Hb}(\mathrm{gm} / \mathrm{dl})$ & $0.487^{*}$ & $<0.001$ \\
Platelets $\left(\mathrm{X} 10^{3} / \mathrm{mm}^{3}\right)$ & 0.079 & 0.584 \\
WBCs $\left(\mathrm{X} 10^{3} / \mathrm{mm}^{3}\right)$ & $0.306^{*}$ & 0.030 \\
Blast in peripheral blood (\%) & $0.781^{*}$ & $<0.001$ \\
Blast in BM (\%) & $0.874^{*}$ & $<0.001$ \\
Serum LDH (U/L) & -0.106 & 0.465 \\
\hline
\end{tabular}

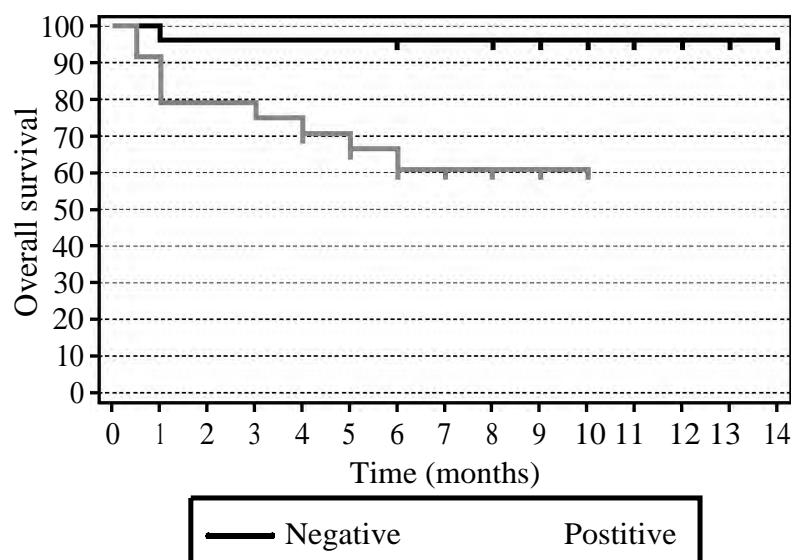

Fig. (1): Kaplan-Meier survival curve for overall survival with CD 105 expression positive and negative groups.

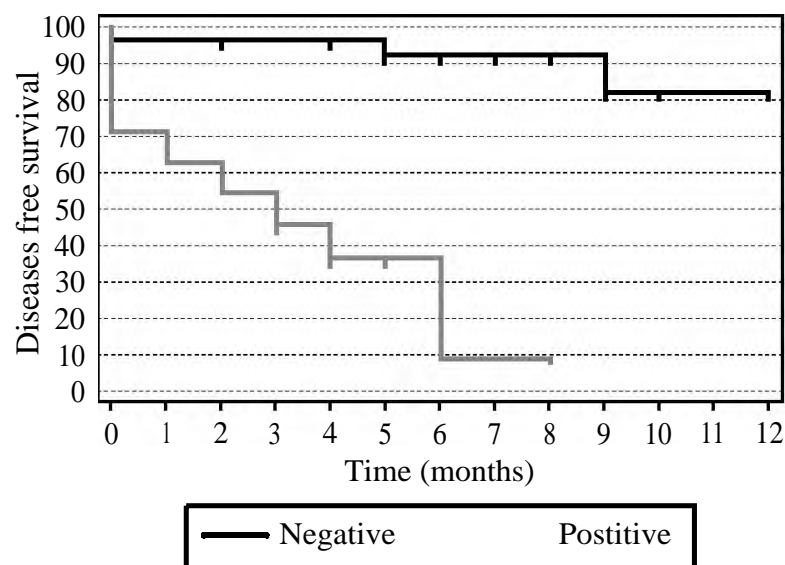

Fig. (2): Kaplan-Meier survival curve for disease free survival with CD105 expression positive and negative groups (died cases were excluded). 


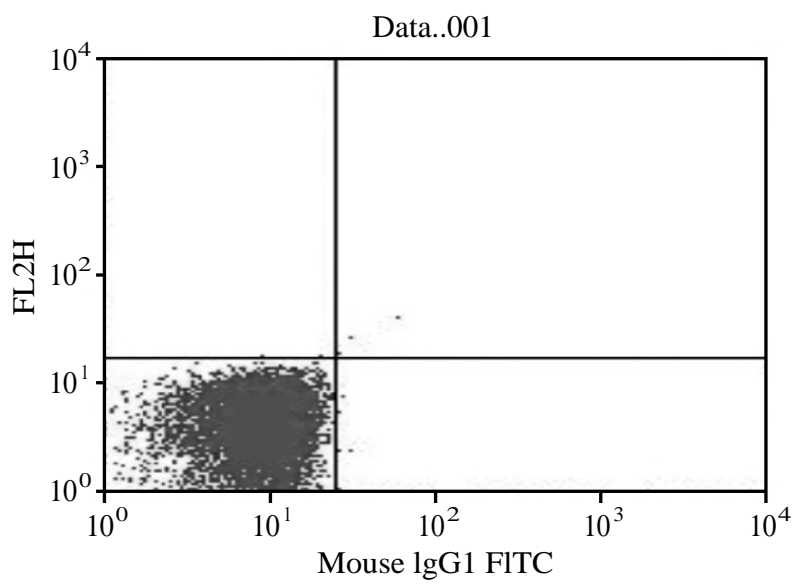

Fig. (3): Flow cytometric analysis represents: Dot plot showing negative control for CD105 expression.

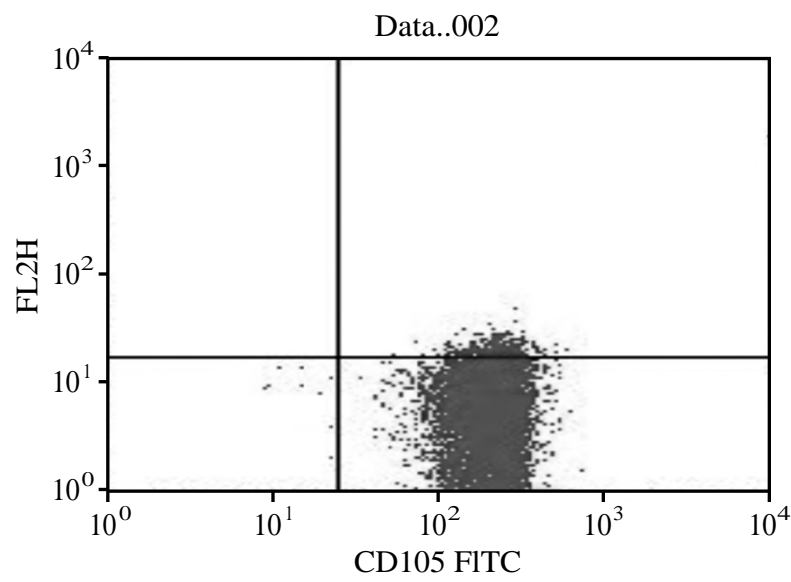

Fig. (4): Flow cytometric analysis represents: Dot plot showing positive CD105 expression.

Table (5): Relation between outcome and CD 105 expression positive and negative groups.

\begin{tabular}{|c|c|c|c|c|c|c|c|c|}
\hline \multirow{3}{*}{$\begin{array}{l}\text { CD105 } \\
\text { expression (\%) }\end{array}$} & \multicolumn{6}{|c|}{ Outcome } & \multirow{3}{*}{$\begin{array}{l}\text { Test of } \\
\text { sig. }\end{array}$} & \multirow{3}{*}{$p$} \\
\hline & \multicolumn{2}{|c|}{$\begin{array}{l}\text { Death } \\
(\mathrm{n}=10)\end{array}$} & \multicolumn{2}{|c|}{$\begin{array}{c}\text { Relapse } \\
(n=11)\end{array}$} & \multicolumn{2}{|c|}{$\begin{array}{c}\text { CR } \\
(n=29)\end{array}$} & & \\
\hline & No. & $\%$ & No. & $\%$ & No. & $\%$ & & \\
\hline Negative $(n=26)$ & 1 & 10.0 & 2 & 18.2 & 23 & 79.3 & $\chi^{2}=$ & $<0.001 *$ \\
\hline Positive ( $n=24)$ & 9 & 90.0 & 9 & 81.8 & 6 & 20.7 & $20.773 *$ & \\
\hline Mean \pm SD & \multicolumn{2}{|c|}{$89.04 \pm 25.38$} & \multicolumn{2}{|c|}{$73.34 \pm 28.84$} & \multicolumn{2}{|c|}{$21.88 \pm 22.39$} & $\mathrm{~F}=$ & $<0.001 *$ \\
\hline Sig. bet. grps & \multicolumn{2}{|c|}{$p_{1} 0.149$} & \multicolumn{2}{|c|}{$p_{2}<0.001^{*}$} & \multicolumn{2}{|c|}{$p_{3}<0.001 *$} & $36.394 *$ & \\
\hline
\end{tabular}

$\chi^{2}, p: \chi^{2}$ and $p$-values for Chi square test.

$\mathrm{F}, p: \mathrm{F}$ and $p$-values for ANOVA test, Sig. bet. grps was done using Post Hoc Test (LSD).

$p_{1} \quad: p$-value for comparing between death and relapse.

$p_{2}: p$-value for comparing between death and CR.

$p_{3}: p$-value for comparing between relapse and CR.

\section{Discussion}

Acute Myelogenous Leukemia (AML) is a clonal, malignant disease of hematopoietic tissues that is characterized by accumulation of abnormal (leukemic) blast cells, principally in the marrow, and impaired production of normal blood cells [11]

Prognosis for the majority of AML patients remains dismal and identification of novel markers for risk stratification and therapeutic targeting is needed [10].

CD105 is overexpressed in tumor-associated endothelium, which modulates angiogenesis and facilitates metastasis. This finding implies that CD 105 has a role in tumor progression through its effects on the stroma. Expression of CD105 by malignant cells also has been documented. Changes in CD105 expression levels in tumor cells contribute to deregulation of TGF- $\beta$-dependent and TGF$\beta$-independent signaling pathways and malignant progression [12].
Flow cytometry is the most important technology for generating correlative information about single cells within heterogenous sample preparations. Advances in technology and fluorophore chemistry allow for the rapid and quantitative measurement of cell parameters in a highly sensitive and reproducible manner [13].

The aim of this study was to evaluate the prognostic value of CD105 expression in AML patients.

According to the age of studied AML patients it ranged from 8 to 75 years with a mean value of $41.54 \pm 18.46$ years. [14] stated that AML can occur in any age, but in general the incidence of AML increases with age. It was found that 27 patients $(54 \%)$ were males and 23 patients $(46 \%)$ were females. This is in concordance with a study done by [15] who reported that, the incidence of AML is higher in males than in females.

As regards the heamoglobin concentration, CD105 expression had a significant positive cor- 
relation with $\mathrm{Hb}$ level. This significant association could be explained by [16], who found that normal human bone marrow CD1 05+/CD34+ subset are identified as Late Erythroid Progenitor (LEP) and can give rise to erythroid colony-forming unit (CFU-E) and quantitative defect in this subset associated with anemia.

CD105 expression was not found to be statistically significantly correlated with platelets count and this is in concordance with [17]. CD105 expression had a significant positive correlation with WBCs count. In contrast [17] who reported that no correlation was found between levels of sCD 105 and White Blood Cells (WBC) count in AML patients.

As regard blast percentage in peripheral blood and BM, CD105 expression had a significant positive correlation with both blast percentage in peripheral blood and BM. This is in concordance with [18] who reported that CD105 positive patients had a significantly higher blast percentage in peripheral blood and higher BM infiltration by myeloblasts. In contrast [17] reported that no correlation was found between levels of sCD 105 and blast percentage in peripheral blood and BM in AML patients.

As regard serum $\mathrm{LDH}$, its level was elevated in all of studied AML patients. Serum LDH is important adverse risk factors for survival and is one of the bad prognostic factors in AML, as noticed by [19]. CD105 expression was not found to be statistically significantly correlated with serum LDH level and this is in concordance with [17]

The expression of CD105 was detected in the bone marrow aspirate by flow cytometry and it was found that CD105 was highly expressed in (48\%) out of studied AML patients. Our results in this aspect agreed with those of [20] who reported that CD105 was expressed in (47\%) of acute myelogenous leukemias and this is in concordance with [7] who reported that (24\%) of AML cases had diffuse and strong CD 105 expression by blasts (more than $80 \%$ positive cells), (30\%) of AML cases were partially positive (20\% to $80 \%$ positive cells) and (46\%) of AML cases were completely negative (less than $20 \%$ positive cells).

As regard $\mathrm{FAB}$ classification and its distribution among patients' groups, there was a significant increase in CD105 expression in cases with M4 than other FAB subtypes. There was a significant difference in percentage of CD105 positive cells between different FAB subtypes. The percentage of CD105 expression is higher in M2 followed by M5 then M4 while M3 showed the less percentage of CD105 expression and these results were in agreement with [20] who reported that CD 105 was always expressed by most immature subtypes, and that it was absent on more differentiated ones as absence of CD105 was restricted to acute promyelocytic leukemias (classically characterized by CD34 negativity) and immunosubtyping of AMLs revealed a more frequent expression of CD105 in monocytic morphology (M4 and M5) especially with apparent expression of CD7 subgroup as compared to CD14-positive cases.

M3 showed the least distribution among CD105 positive group and least percentage of CD105 expression and this is in concordance with [20] who reported that leukaemic promyelocytes lacked the precursor antigen CD105 but in contrast with [7] who reported that $(100 \%)$ of 9 M3 AML patients with $t(15 ; 17)$ (q24.1;q21.2)/PML-RARA showed diffuse and strong expressed of CD105 by blasts.

By comparing between groups, it was found that patients with positive CD105 expression had a significant lower $\mathrm{CR}$ rate and a significant higher relapse and death rate. Thus, there was a significant association between CD105 expression and poor outcome of patients. These findings were in concordance with [21] who reported that lower CR and higher relapse rate were found among AML patients with high expression of angiogenic factors including CD105.

Overall Survival (OS) and Disease Free Survival (DFS) were evaluated in both positive and negative CD105 expression groups using Kaplan-Meier survival curve. A significant decrease in both OS and DFS was found in positive CD105 expression group as compared with negative CD105 expression group. These findings were in concordance with [18] who reported that CD105 associated with increased leukemogenic activity of blast cells and decrease both OS and DFS.

\section{Conclusion:}

Positive CD105 expression levels are associated with a bad outcome in AML patients and its expression can be easy determined in routine flow cytometric analysis. Therefore, it should be regularly investigated as a bad prognostic factor for assessment of AML patients.

\section{Conflicts of interest:}

No conflicts of interest declared. 


\section{Authors' contributions:}

All authors had equal role in design, work, statistical analysis and manuscript writing.

\section{References}

1- MARGARET R., O'DONNELL, C.N. ABBOUD, ALTMAN J., APPELBAUM F.R., DANIEL A., ATTAR E., BORATE U., COUTRE S., DAMON L.E., GOORHA S., LANCET J., MANESS L., MARCUCCI G., MILLENSON M., MOORE J., RAVANDI F., SHAMI J. and SMITH B.: Acute myeloid leukemia. Journal Natl. Compr. Canc. Netw., 10: 984-1021, 2012.

2- SMITH M.L., HILLS R.K. and GRIMWADE D.: Independent prognostic variables in acute myeloid leukaemia. Journal Blood Reviews, 25 (1): 39-51, 2011.

3- TALLMAN M.S., GILLILAND D.G. and ROWE J.M.: Drug therapy for acute myeloid leukemia. Blood, 106 (4): 1154-63, 2005.

4- GODOY C.R., LEVY D., GIAMPAOLI V., CHAMONE D.A., BYDLOWSKI S.P. and PEREIRA J.: Circulating endothelial cells are increased in chronic myeloid leukemia blast crisis. Braz. J. Med. Biol. Res., 48 (6): 509-14, 2015.

5- WIERZBOWSKA A., ROBAK T. and KRAWCZYNSKA A.: Kinetics and apoptotic profile of circulating endothelial cells as prognostic factors for induction treatment failure in newly diagnosed acute myeloid leukemia patients. Ann. Hematol., 87 (2): p. 97, 2008.

6- FONSATTI E., ALTOMONTE M., NICOTRA M.R., NATALI P.G. and MAIO M.: Endoglin (CD105): A powerful therapeutic target on tumorassociated angiogenetic blood vessels. Oncogene, 22 (42): 6557-63, 2003.

7- CHAKHACHIRO Z.I., ZUO Z., ALADILY T.N., KANTARJIAN H.M., CORTES J.E., ALAYED K., NGUYEN M.H., MEDEIROS L.J. and BUESO-RAMOS C.: CD105 (endoglin)is highly overexpressed in a subset of cases of acute myeloid leukemias. Am. J. Clin. Pathol., 140 (3): 370-8, 2013.

8- DUFF S.E., LI C., GARLAND J.M. and KUMAR S.: CD105 is important for angiogenesis: Evidence and potential applications. FASEB J., 17 (9): 984-92, 2003.

9- De GREEF G.E., VAN PUTTEN W.L., BOOGAERTS M., HUIJGENS P.C., VERDONCK L.F., VELLENGA E., THEOBALD M., JACKY E. and LÖWENBERG B.: Criteria for defining a complete remission in acute myeloid leukaemia revisited. An analysis of patients treated in HOVON SAKK co-operative group studies. Br. J. Haematol., 128 (2): 184-91, 2005.

10-DÖHNER H., ESTEY E.H., AMADORI S., APPELBAUM F.R., BÜCHNER T., BURNETT A.K., DOMBRET H., FENAUX P., GRIMWADE D., LARSON R.A., LOCOCO F., NAOE T., NIEDERWIESER D., OSSENKOPPELE G.J., SANZ M.A., SIERRA J., TALLMAN M.S., LÖWENBERG B. and BLOOMFIELD C.D.: Diagnosis and management of acute myeloid leukemia in adults: Recommendations from an international expert panel, on behalf of the European Leukemia Net. Blood, 115 (3): 453-74, 2010.

11- DÖHNER H., WEISDORF D.J. and BLOOMFIELD C.D.: Acute Myeloid Leukemia. N. Engl. J. Med., 373 (12): 1136-52, 2015.

12- PEREZ-GOMEZ E., DEL CASTILLO G. and JUAN FRANCISCO S.: The role of the TGF-beta coreceptor endoglin in cancer. Sci. World J., 10: 2367-84, 2010.

13- De ROSA S.C., MITRA D.K., WATANABE N., HERZENBERG L.A., HERZENBERG L.A. and ROEDERER M.: Vdelta1 and Vdelta2 gammadelta $T$ cells express distinct surface markers and might be developmentally distinct lineages. J. Leukoc. Biol., 70 (4): 518-26, 2001.

14- BELSON M., KINGSLEY B. and HOLMES A.: Risk factors for acute leukemia in children: A review. Environ. Health Perspect, 115 (1): 138-45, 2007.

15- JEMAL A., SIEGEL R., WARD E., HAO Y., XU J., MURRAY T. and THUN M.J.: Cancer statistics, 2008. CA Cancer J. Clin., 58 (2): 71-96, 2009.

16- ISKANDER D., PSAILA B., GERRARD G., CHAIDOS A., EN FOONG H., HARRINGTON Y., KARNIK L.C., ROBERTS I., De La FUENTE J. and KARADIMITRIS A.: Elucidation of the EP defect in Diamond-Blackfan anemia by characterization and prospective isolation of human EPs. Blood, 125 (16): 2553-7, 2015.

17- CALABRÒ L., FONSATTI E., BELLOMO G., ALONCI A., COLIZZI F., SIGALOTTI L., ALTOMONTE M., MUSOLINO C. and MAIO M.: Differential levels of soluble endoglin (CD105) in myeloid malignancies. J. Cell Physiology, 194 (2): 171-5, 2002.

18-DOURADO K.C., BAIK J., OLIVEIRA V.P., BELTRAME M., YAMAMOTO A., THEUER C.P., FIGUEIREDO C.V., VERNERIS M.R. and PERLINGEIRO R.R.: Endoglin: A novel target for therapeutic intervention in acute leukemias revealed in xenograftmouse models. Blood, 129 (18): 2526-36, 2017.

19- DOMINGO-CLAROS A., LARRIBA I., ROZMAN M., IRRIGUIBLE D. and AVENTIN A.: Acute erythroid neoplastic proliferation. A biological study based on 62 patients. Haematologica, 87: 148-53, 2002.

20- FONSATTI E., DEL VECCHIO L., ALTOMONTE M., SIGALOTTI L., NICOTRA M.R., CORAL S., NATALI P.G. and MAIO M.: Endoglin: An accessory component of the TGF-beta-binding receptor-complex with diagnostic prognostic, and bioimmunotherapeutic potential in human malignancies. J. Cell Physiol., 188 (1): 1-7, 2001.

21- PADRÓ T., RUIZ S., BIEKER R., BÜRGER H., STEINS M., KIENAST J., BÜCHNER T., BERDEL W.E. and MESTERS M.R.: Increased angiogenesis in the bone marrow of patients with acute myeloid leukemia. Blood, 95: p. 8, 2000. 


\section{الدور التعبيرى للآندوجلن فى مرضى سرطان الدم الميلودى الحاد}

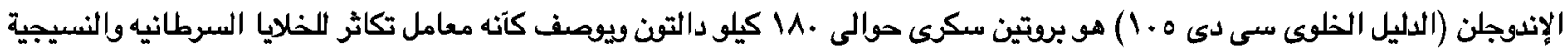

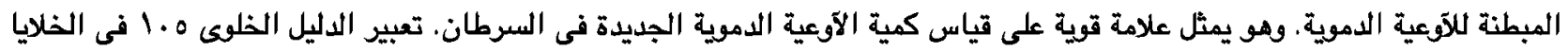

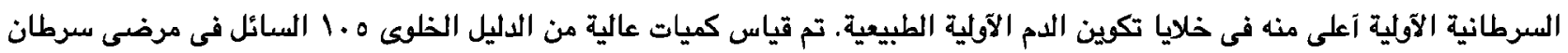

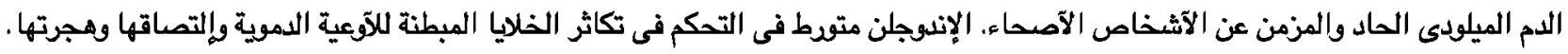

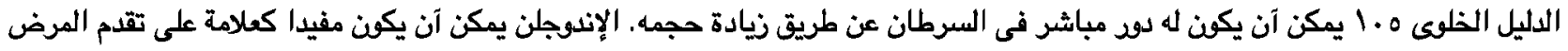
والتعرف على المريض الاكثر عرضه للإنتكاسه وإنتشار السرطان.

الهدف من البحث: تقييم الدود التعبيرى للإندوجلن (الدليل الخلوى سى دى ه ـ1) فى مرضى سرطان الدم الميلودى الهاد وتوضيح دوره كعلامة إنذار.

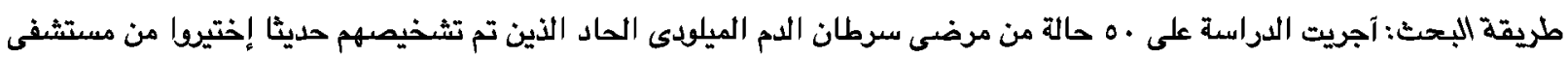

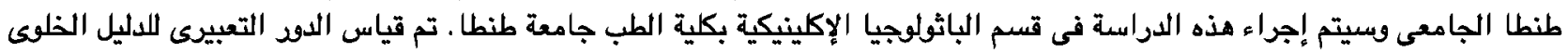

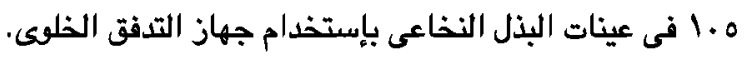

تم تقسيم الآفراد إلى مجموعتين بالنسبة للدود التعبيرى للإندوجلن مجموعة إيجابية وآخرى سلبية.

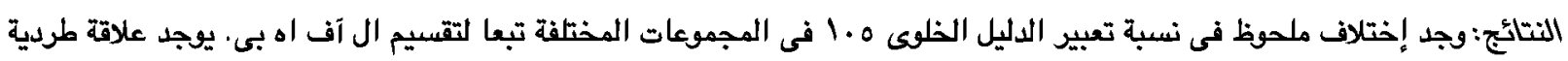

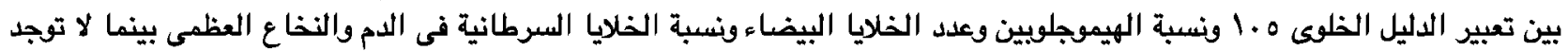

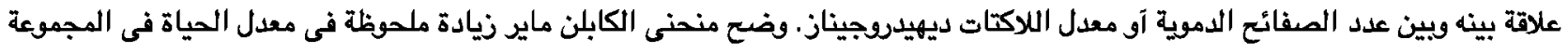

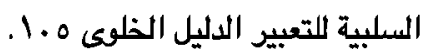

